\title{
Zinc- and arsenic-resistant strains of Thiobacillus ferrooxidans have increased copy numbers of chromosomal resistance genes
}

\author{
Tamara F. Kondratyeva, ${ }^{1}$ Lyudmila N. Muntyan ${ }^{2}$ and \\ Grygory I. Karavaiko²
}

Author for correspondence: Tamara F. Kondratyeva. Tel: +7951356596.

Research Group of

Genosystematics and

Evolution of Bacteria' ${ }^{1}$ and

Laboratory of Microbial

Transformation of Minerals²,

Institute of Microbiology,

Russian Academy of

Sciences, Moscow 117811,

Prospekt 60-let Octyabrya,

7/2, Russia

\begin{abstract}
Pulsed-field gel electrophoresis (PFGE) was used to examine chromosomal DNA from various strains of Thiobacillus ferrooxidans: these were the reference strain VKM-458, strains isolated from different environments and pilot plants for processing gold-bearing concentrates, and strains experimentally adapted to high zinc and arsenic concentrations in growth medium. The restriction endonuclease Xbal digested $T$. ferrooxidans VKM-458 chromosomal DNA into a number of fragments sufficient for identification of their size and calculation of the size of the entire genome $(2855 \pm 44 \mathrm{~kb})$. Restriction fragment length polymorphism of the chromosomal DNA in various strains suggests the usefulness of this approach for analysis of the diversity of $T$. ferrooxidans strains and for the study of strain stability under conditions of industrial utilization. A comparison of Xbal-restriction patterns in parent strains and in strains with acquired enhanced resistance to zinc or arsenic revealed amplification of certain fragments in the resistant strains, i.e. a $98 \mathrm{~kb}$ fragment in strain TFZ and a 28 kb fragment in strain VKM-458As2. We suggest that the enhanced resistance to toxic metals in $T$. ferrooxidans is gained through increase of the copy number of resistance genes and enhanced synthesis of proteins involved in resistance.
\end{abstract}

Keywords: pulsed-field gel electrophoresis (PFGE), restriction patterns, restriction fragment length polymorphism (RFLP), arsenic resistance, zinc resistance

\section{INTRODUCTION}

Thiobacillus ferrooxidans is a Gram-negative, acidophilic, obligately lithotrophic bacterium which derives the energy required for growth from the oxidation of iron or reduced sulfur compounds and possesses high resistance to toxic metal ions. Its peculiar metabolic properties make T. ferrooxidans an important bacterium in the iron and sulfur cycles of extreme environments. T. ferrooxidans is also one of the most important micro-organisms employed for metal-leaching in mining processes, stimulating genetic studies of this bacterium. The achievements in the molecular genetics of T. ferrooxidans in the last decade have been reviewed by Rawlings \& Kusano (1994). Recently, Peng et al. (1994) demonstrated the transfer of broad-host-range plasmids and transposons

Abbreviations: PFGE, pulsed-field gel electrophoresis; RFLP, restriction fragment length polymorphism. from Escherichia coli to $T$. ferrooxidans by conjugation and expression of selective markers. This group showed that arsenic-resistance genes, derived from plasmid R773 and introduced into $T$. ferrooxidans strains, significantly enhanced $T$. ferrooxidans resistance to $\mathrm{NaAsO}_{2}$. The success in molecular genetics of $T$. ferrooxidans suggests its application for improvement of industrial bioleaching processes.

The aim of the present work was to reveal structural changes in chromosomal DNA of $T$. ferrooxidans strains that occur under the influence of varied growth conditions. We used pulsed-field gel electrophoresis (PFGE) to separate the DNA fragments generated by the restriction endonuclease $X b a I$. We present the characteristics of chromosomal DNA from the reference strain T. ferrooxidans VKM-458, from collection strains, strains isolated from different habitats (ore deposits, mineral processing plants), and strains with experimentally enhanced resistance to zinc and arsenic ions. 


\section{METHODS}

Bacterial strains and growth conditions. The strains of $T$. ferrooxidans used in the study are presented in Table 1 . The strains were maintained at $4^{\circ} \mathrm{C}$ in Silverman-Lundgren medium (Silverman \& Lundgren, 1959) or on the same medium solidified with $0.5 \%$ agarose (Lachema). Bacterial cells for DNA isolation were grown overnight in $250 \mathrm{ml}$ Erlenmeyer flasks, containing $50 \mathrm{ml}$ medium, on a rotary shaker $(150$ r.p.m. $)$ at $28^{\circ} \mathrm{C}$. The initial $\mathrm{pH}$ of the medium was $1 \cdot 8-2 \cdot 0$. Cells in late exponential phase were harvested by centrifugation at $50000 \mathrm{~g}$ for $50 \mathrm{~min}$ at $4^{\circ} \mathrm{C}$, and washed successively with sterile medium, $0.005 \mathrm{M}$

\section{Table 1. T. ferrooxidans strains used in this study}

T. ferrooxidans strains are kept in the Culture Collection of the Laboratory of Microbial Transformation of Minerals, Institute of Microbiology, Russian Academy of Sciences.

\begin{tabular}{|c|c|c|c|}
\hline Strain & $\begin{array}{l}\text { Year of } \\
\text { isolation }\end{array}$ & Isolation site & Source or reference \\
\hline VKM-458 & 1957 & $\begin{array}{l}\text { Mine runoff containing iron, coal field, } \\
\text { near Moscow, Russia }\end{array}$ & $\begin{array}{l}\text { N. N. Lyalikova, Institute } \\
\text { of Microbiology, Russian } \\
\text { Academy of Sciences, } \\
\text { Moscow, Russia }\end{array}$ \\
\hline TFY & 1969 & Yugoslavia & $\begin{array}{l}\text { Received from } \\
\text { D. Maryanovich }\end{array}$ \\
\hline VKM-1160 & 1971 & $\begin{array}{l}\text { Sibaiskiy copper-zinc deposit, South Ural, } \\
\text { Russia }\end{array}$ & G. I. Karavaiko \\
\hline TFP & 1974 & Peru & $\begin{array}{l}\text { Received from } \\
\text { K. Cardozo, Instituto } \\
\text { Geologico Minero Y } \\
\text { Metalurgico, Lima, Peru, } \\
\text { in } 1987\end{array}$ \\
\hline TF-16 & 1976 & Canada & $\begin{array}{l}\text { Received from A. Torma, } \\
\text { INEL/EG \& G. Igaho } \\
\text { Inc., Idaho Falls, Idaho, } \\
\text { USA }\end{array}$ \\
\hline TFV-1 & 1977 & $\begin{array}{l}\text { Volkovskiy copper deposit, processing } \\
\text { plant, Central Ural, Russia }\end{array}$ & G. I. Karavaiko \\
\hline TFN & 1979 & $\begin{array}{l}\text { Nikolaevskiy copper-zinc deposit, } \\
\text { processing plant, Central Ural, Russia }\end{array}$ & G. I. Karavaiko \\
\hline TFR2 & 1987 & $\begin{array}{l}\text { Spring on the gully slope, Kunashir Island, } \\
\text { far east of Russia }\end{array}$ & E. S. Kalyaeva \\
\hline TF-30 & 1988 & $\begin{array}{l}\text { Tailings, Balkhashskiy copper-zinc deposit, } \\
\text { Kazakhstan }\end{array}$ & G. I. Karavaiko \\
\hline ATCC 19859 & & USA & $\begin{array}{l}\text { Received from D. Holmes, } \\
\text { Clarkson University } \\
\text { Potsdam, New York, } \\
\text { USA, in } 1988\end{array}$ \\
\hline TFT & 1989 & $\begin{array}{l}\text { Pyrite concentrate, } 0.005 \% \text { arsenic, } \\
\text { processing plant, Kumtorskiy deposit, } \\
\text { Kyrgyzstan }\end{array}$ & L. N. Muntyan \\
\hline TFM & 1989 & $\begin{array}{l}\text { Arsenopyrite concentrate, } 10-15 \% \text { arsenic, } \\
\text { Zarmitanskiy deposit, Uzbekistan }\end{array}$ & L. N. Muntyan \\
\hline TFD & 1991 & $\begin{array}{l}\text { Arsenopyrite concentrate, } 5-6 \% \text { arsenic, } \\
\text { processing plant, Darasunskiy deposit, } \\
\text { Transbaikal region, Russia }\end{array}$ & L. N. Muntyan \\
\hline TFBk & 1991 & $\begin{array}{l}\text { Arsenopyrite concentrate, } 6 \% \text { arsenic, } \\
\text { processing plant, Bakyrchikskiy deposit, } \\
\text { Kazakhstan }\end{array}$ & L. N. Muntyan \\
\hline TF-1292 & 1992 & $\begin{array}{l}\text { Arsenopyrite concentrate, } 3-4 \% \text { arsenic, } \\
\text { processing plant, Olimpiadinskiy deposit, } \\
\text { Krasnoyarsk region, Russia }\end{array}$ & L. N. Muntyan \\
\hline VKM-458As2 & 1993 & Selected in the present study & L. N. Muntyan \\
\hline TFZ & 1993 & Selected in the present study & G. I. Karavaiko \\
\hline
\end{tabular}


Chromosomal DNA in T. ferrooxidans strains

$\mathrm{H}_{2} \mathrm{SO}_{4}$, water, and $0.05 \mathrm{M}$ EDTA. Zinc was introduced to the medium in the form of $\mathrm{ZnSO}_{4} \cdot 7 \mathrm{H}_{2} \mathrm{O}$. The content of zinc in the medium was determined with a Perkin Elmer 3100 atomic absorption spectrometer.

Arsenic resistance of $T$. ferrooxidans. This was studied in cultures growing on solid medium. All components of the medium were sterilized separately and mixed immediately prior to pouring in Petri dishes. Arsenic was introduced in the form of $\mathrm{Na}_{3} \mathrm{AsO}_{3}$ solution to make up the following concentrations of $\mathrm{As}^{3+}\left(\mathrm{g} \mathrm{l}^{-1}\right): 0 \cdot 5,1 \cdot 0,1 \cdot 5,2 \cdot 0,3 \cdot 0,4 \cdot 0$. Five-day slant cultures of $T$. ferrooxidans on the agarose medium without arsenic were used as an inoculum. After inoculation by streak plating, dishes were incubated at $28^{\circ} \mathrm{C}$, and growth followed for $14 \mathrm{~d}$.

Preparation of intact genomic DNA and restriction digests. Cell suspension $(300 \mu \mathrm{l})$ was mixed at $42{ }^{\circ} \mathrm{C}$ with $450 \mu \mathrm{l} 1 \cdot 1 \%$ $(\mathrm{w} / \mathrm{v}$ ) solution of low-melting-point agarose (Serva) in $0.125 \mathrm{M}$ EDTA. The liquid mixture was pipetted into plastic moulds (less than $1 \mathrm{~mm}$ thick) and allowed to solidify at $4{ }^{\circ} \mathrm{C}$ for at least $20 \mathrm{~min}$. The hardened agarose blocks were then pushed into $0.5 \mathrm{M}$ EDTA, $\mathrm{pH} 8.0$, which contained $1 \%(\mathrm{w} / \mathrm{v})$ sodium lauroylsarcosine (Sigma) and proteinase $\mathrm{K}\left(200 \mu \mathrm{g} \mathrm{ml}^{-1}\right)$ in $0.5 \mathrm{M}$ EDTA. Blocks were kept at room temperature for $1 \mathrm{~h}$ and then incubated at $55^{\circ} \mathrm{C}$ for $16 \mathrm{~h}$. Prepared blocks were carefully washed with distilled water and kept in $0.5 \mathrm{M}$ EDTA at $4{ }^{\circ} \mathrm{C}$. Inserts to suit the sizes of the gel plate wells were cut from the blocks, washed with distilled water, and then incubated in digestion buffer specific for each restriction endonuclease. Since the $\mathrm{G}+\mathrm{C}$ content of $T$. ferrooxidans DNA exceeds $50 \mathrm{~mol} \%$ (Karavaiko, 1989), enzymes with GC-poor recognition sites were tested. The genomic DNA was digested with 14 restriction enzymes: $B c l \mathrm{I}, B g / \mathrm{II}, B s p 119 \mathrm{I}, B s u 15 \mathrm{I}, D r a \mathrm{I}$, Eco32I, EcoRI, HindIII, MboI, MunI, Ppu10I, PvuI, ScaI, XbaI. Restriction endonucleases were obtained from MBI Fermentas, Lithuania. Restriction endonuclease digestions were performed in $30 \mu \mathrm{l}$ restriction buffer with $40 \mathrm{U}$ enzyme at $37^{\circ} \mathrm{C}$ for $2 \mathrm{~h}$. After digestion, the buffer was aspirated, gel inserts were stained with bromophenol blue, and then loaded in wells of a $1 \%(\mathrm{w} / \mathrm{v})$ agarose gel in $0.5 \times$ TBE $(1 \times$ TBE is $90 \mathrm{mM}$ Tris base, $90 \mathrm{mM}$ boric acid, 2.5 mM EDTA, pH 8.0).

DNA fragment separation. PFGE was used to separate DNA fragments with a device constructed by the science-industrial cooperative 'Diagnosticum'. Separation was performed in $0.5 \times$ TBE at $10-13 \mathrm{~V} \mathrm{~cm}^{-1}$. Pulse time and duration of electrophoresis were varied depending on the required resolution range. The running buffer temperature was noted in each experiment. Gels were stained with ethidium bromide and photographed as described by Carle \& Olson (1985). Lambda DNA concatamers and lambda DNA digested with HindIII were used as molecular mass standards and prepared as described by Mathew et al. (1988).

\section{RESULTS AND DISCUSSION}

\section{Characterization of chromosomal DNA of T. ferrooxidans VKM-458}

Digestion of DNA with $X b a \mathrm{I}$ permitted measurement of fragment size and the size of the entire genome. PFGE conducted under the varied pulse times allowed us to determine the size of DNA fragments represented by 21 separate bands on electrophoretograms (Table 2). Bands that were unusually bright might consist of two or more different restriction fragments of similar size. An average size of no less than $2855 \pm 44 \mathrm{~kb}$ was calculated for the $T$. ferrooxidans VKM-458 genome. Based on kinetics of
Table 2. Sizes of Xbal-generated restriction fragments of genomic DNA from $T$. ferrooxidans as separated by PFGE

\begin{tabular}{|cccl|}
\hline $\begin{array}{l}\text { Fragment } \\
\text { no. }\end{array}$ & $\begin{array}{c}\text { Size } \\
\mathbf{( k b )}\end{array}$ & $\begin{array}{c}\text { Fragment } \\
\text { no. }\end{array}$ & $\begin{array}{l}\text { Size } \\
\mathbf{( k b )}\end{array}$ \\
\hline 1 & $320 \pm 6$ & 12 & $67 \pm 2^{*}$ \\
2 & $230 \pm 1$ & 13 & $61 \pm 1$ \\
3 & $202 \pm 1$ & 14 & $56 \pm 1$ \\
4 & $179 \pm 3$ & 15 & $51 \pm 1^{*}$ \\
5 & $165 \pm 4$ & 16 & $44 \pm 1^{*}$ \\
6 & $147 \pm 6^{*}$ & 17 & $28 \pm 1^{*}$ \\
7 & $129 \pm 7$ & 18 & $26 \cdot 5 \pm 0 \cdot 5^{*}$ \\
8 & $99 \pm 2^{*}$ & 19 & $24 \cdot 5 \pm 0 \cdot 3$ \\
9 & $94 \pm 2^{*}$ & 20 & $19 \cdot 5 \pm 0 \cdot 4^{*}$ \\
10 & $80 \pm 2^{*}$ & 21 & $17 \cdot 5 \pm 0 \cdot 3 *$ \\
11 & $71 \pm 1^{*}$ & & \\
\hline
\end{tabular}

* Designates doublet or more.

DNA reassociation, Yates \& Holmes (1987) calculated the T. ferrooxidans ATCC 19859 genome size at $2800 \mathrm{~kb}$. Variations in genome sizes of different strains could be caused by structural changes resulting from deletions, duplications or insertions. It is the opinion of several authors (Leblond et al., 1990; Tudor et al., 1990) that estimates of microbial genome sizes made by PFGE are more accurate than those obtained by other methods.

\section{Comparison of Xbal-restriction patterns of chromosomal DNA in different $T$. ferrooxidans strains}

$X b a I$-restriction patterns were studied in $T$. ferrooxidans strains isolated from various ores and concentrates (Fig. 1). Two strains, VKM-458 and TF-30, showed similarities in their restriction patterns, whereas the other strains had unique patterns. Fig. 1 shows the distinctive patterns of bands on electrophoretograms of DNA fragments. Digestion of chromosomal DNA from different $T$. ferrooxidans strains into fragments of various lengths is indicative of diverse arrangement of $\mathrm{XbaI}$-restriction sites, i.e. restriction fragment length polymorphism (RFLP). In view of the complex composition of oxidation substrates and broad-range of the original habitat conditions, it is difficult to identify the factors responsible for the change in location of $X b a I$-restriction sites in chromosomal DNA of different $T$. ferrooxidans strains.

Unique restriction patterns observed in various $T$. ferrooxidans strains suggested that PFGE may serve as a reliable method for identification of new strains. Previously, other authors came to the same conclusion based on the analysis of strain polymorphism of the DNA restriction patterns in other micro-organisms (Grothues \& Tummler, 1987; Le Bourgeois et al., 1989; Bender et al., 1990; Giovannetti et al., 1990; Okahashi et al., 1990; Tanskanen et al., 1990; Zakrzewska-Czerwinska et al., 1990). Analysis of chromosomal DNA by PFGE also provides a means by which $T$. ferrooxidans cultures may be 


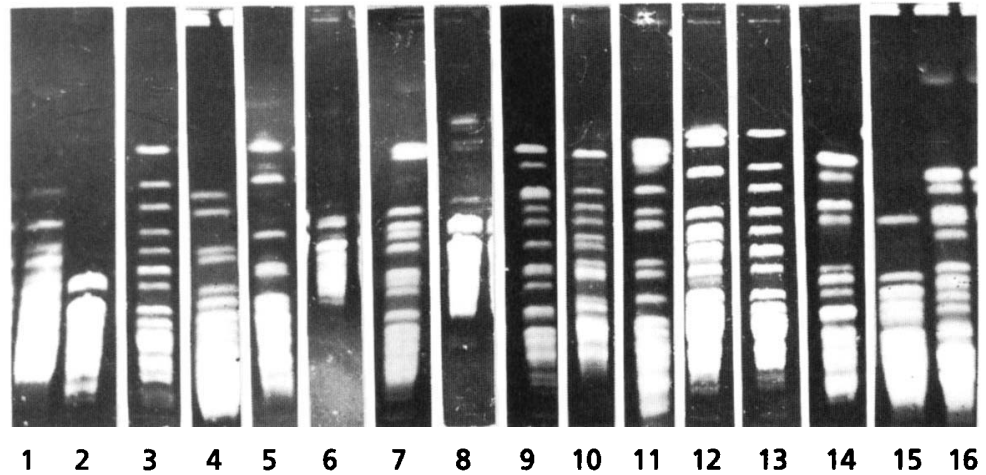

Fig. 1. PFGE separation of Xbal-generated genomic DNA fragments from different $T$. ferrooxidans strains. The PFGE conditions were $12 \mathrm{~V} \mathrm{~cm}^{-1}, 25 \mathrm{~s}$ pulse, $44 \mathrm{~h}$ run at 12-14 ${ }^{\circ} \mathrm{C}$. Lanes: 1, TFT; 2, TF-16; 3, VKM458; 4, TF-1292; 5, TFN; 6, TFZ; 7, TFP; 8 , TFY; 9 , TFBK; 10 , TFR-2; 11, TFV-1; 12 , VKM$1160 ; 13$, TF-30; 14, ATCC 19859; 15, TFD; 16, TFM.

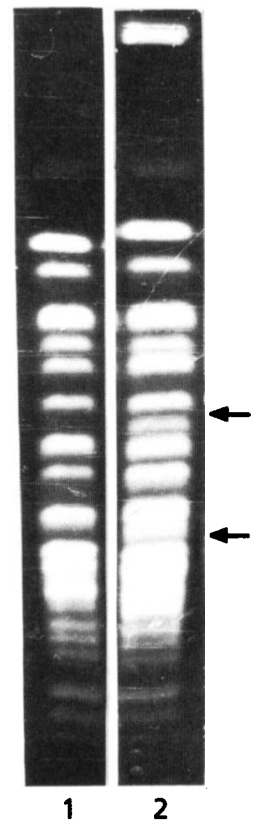

Fig. 2. PFGE separation of Xbal-generated genomic DNA fragments from $T$. ferrooxidans TFBk grown on the medium with one of two oxidation substrates. The PFGE conditions were $12 \mathrm{~V} \mathrm{~cm}^{-1}, 25 \mathrm{~s}$ pulse, $44 \mathrm{~h}$ run at $11^{\circ} \mathrm{C}$. Lanes: 1 , with $\mathrm{FeSO}_{4} .7 \mathrm{H}_{2} \mathrm{O} ; 2$, with $5 \%(\mathrm{w} / \mathrm{V})$ concentrate from Olympiadinskiy deposit (6.4\% $\mathrm{FeS}_{2}, 7.2 \%$ FeAsS, $25.3 \%$ FeS, $1.5 \% \mathrm{Sb}_{2} \mathrm{~S}_{3}, 0.3 \%$ $\mathrm{CuFeS}_{2}, \mathrm{PbS}$ and $\mathrm{ZnS}$ ). Arrows indicate the new fragments.

monitored when used in biotechnological metal leaching: the dominant strain can be identified, strain stability can be followed, and competition between the experimentally selected strains can be studied. By this means we have identified strains of $T$. ferrooxidans which dominated during growth in a medium with high zinc content. PFGE profiles changed according to the substrate being oxidized. An example of the appearance of new fragments is presented in Fig. 2. In the opinion of Rawlings \& Kusano (1994), T. ferrooxidans would have a limit for genetic exchange with other soil micro-organisms as the result of its living in extreme conditions. These authors exclude an occurrence of an unusually large amount of genetic drift in T. ferrooxidans. We did not specifically study this problem. However, instability of the XbaIrestriction site localization in chromosomal DNA of this bacterium and plasmid and transposon transfer from $E$. coli to $T$. ferrooxidans by conjugation (Peng et al., 1994) suggest a significant genetic drift.

\section{Characteristics of chromosomal DNA in T. ferro- oxidans strains with different zinc resistance}

$X b a I$-restriction patterns of chromosomal DNA were compared in two $T$. ferrooxidans strains: the parent strain TFY resistant to $40 \mathrm{~g} \mathrm{Zn}^{2+} 1^{-1}$ and the selective strain TFZ resistant to $70 \mathrm{~g} \mathrm{Zn}^{2+} 1^{-1}$. The latter strain was obtained in the process of adaptation of the parent strain to increasing concentrations of zinc ions (from 40 to $90 \mathrm{~g} \mathrm{l}^{-1}$ ) in the medium. The restriction pattern of the chromosomal DNA in strain TFZ is similar to that in strain TFY in the fragment size range below $160 \mathrm{~kb}$ (Fig. $3 a)$. However, the restriction pattern of strain TFY contained fragments of $352,304,262,224,210,198,182$ and $170 \mathrm{~kb}$ which were missing from the restriction pattern of the selected strain TFZ. The intensity of fluorescence of at least six upper bands differed from the fluorescence of the equimolecular amount of the same-size fragments from chromosomal DNA. It seems likely that the fragments from strain TFY contain the XbaIrestriction sites less susceptible to digestion as compared to the same sites in DNA of strain TFZ. One possible reason may lie in methylation of some restriction sites in chromosomal DNA of strain TFY. In the XbaI-restriction pattern of chromosomal DNA from strain TFZ, we observed more intense fluorescence of a band corresponding to $98 \mathrm{~kb}$ fragments as compared to fluorescence of the same band in the restriction pattern of the parent strain (Fig. 3b). These data permit the following suggestions: (1) the gene coding for zinc resistance is located in the $98 \mathrm{~kb}$ fragment of DNA since the zinc content was the only varied parameter of the medium in selection of strain TFZ; (2) adaptation of the culture to growth under increased zinc concentration caused amplification of the $98 \mathrm{~kb}$ fragment; (3) the increase of zinc-resistance gene copy number leads to increased synthesis of encoded proteins involved in operation of the resistance mechanism with the resulting enhancement of zinc resistance; 


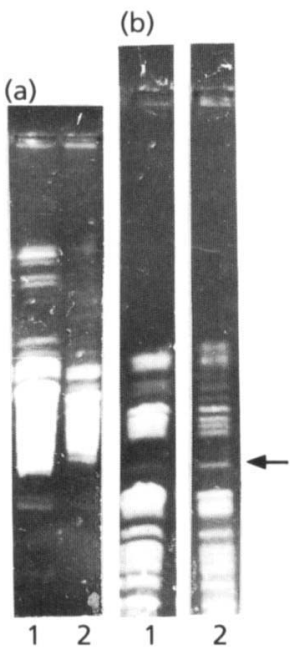

Fig. 3. PFGE separation of Xbal-generated genomic DNA fragments from two strains of $T$. ferrooxidans. (a) $12 \mathrm{~V} \mathrm{~cm}^{-1}$, $25 \mathrm{~s}$ pulse, $44 \mathrm{~h}$ run, $12^{\circ} \mathrm{C}$; (b) $13 \mathrm{~V} \mathrm{~cm}^{-1}, 10 \mathrm{~s}$ pulse, $68 \mathrm{~h}$ run, $13^{\circ} \mathrm{C}$. Lanes: 1 , strain TFY; 2 , strain TFZ. The $98 \mathrm{~kb}$ fragment is indicated by an arrow.

(4) the resistance operon is regulated by zinc ions serving as an inducer.

\section{Characteristics of chromosomal DNA in T. ferro- oxidans strains with different arsenic resistance}

We also compared $X b a I$-restriction patterns of two $T$. ferrooxidans strains: the parent strain VKM-458 and strain VKM-458As2. Strain VKM-458As2 was isolated from an individual colony on a solid medium inoculated with strain VKM-458As1 which was obtained as the result of 10 transfers of $T$. ferrooxidans VKM-458 culture in a liquid medium with an arsenopyrite concentrate at a pulp density of $10 \%(\mathrm{w} / \mathrm{v})$. The content of arsenic in the concentrate was $6.5 \%$ by weight. The minimal inhibitory concentrations for strains VKM-458, VKM-458As1, and VKM458As2 were 1,3 , and $4 \mathrm{~g} \mathrm{As}^{3+} 1^{-1}$, respectively. PFGE analysis of $\mathrm{XbaI}$-restriction patterns, under the conditions which provide resolution of fragments larger than $100 \mathrm{~kb}$ $\left(12 \mathrm{~V} \mathrm{~cm}^{-1}, 25 \mathrm{~s}\right.$ pulse, $11^{\circ} \mathrm{C}, 44 \mathrm{~h}$ run), did not show a distinction between the parent strain and strain VKM458As2 possessing higher arsenic-resistance (Fig. 4a). No differences between the restriction patterns were revealed under PFGE conditions that resolved fragments within the size range $50-100 \mathrm{~kb}\left(10 \mathrm{~V} \mathrm{~cm}^{-1}, 10 \mathrm{~s}\right.$ pulse, $19^{\circ} \mathrm{C}$, $69 \mathrm{~h}$ run) (Fig. 4b). However, PFGE performed at $12 \mathrm{~V} \mathrm{~cm}^{-1}$, with a $5 \mathrm{~s}$ pulse, at $20^{\circ} \mathrm{C}$ for a $68 \mathrm{~h}$ run revealed a greater fluorescence of one band in the restriction pattern of VKM-458As2 (Fig. 4c), even though the total content of DNA was less than in the restriction pattern of strain VKM-458. This band corresponded to fragments of $28 \mathrm{~kb}$. Since this phenomenon was observed with a strain adapted to growth with arsenopyrite concentrate and exhibiting enhanced resistance to $\mathrm{As}^{3+}$ ions, one may assume the localization of arsenic-resistance
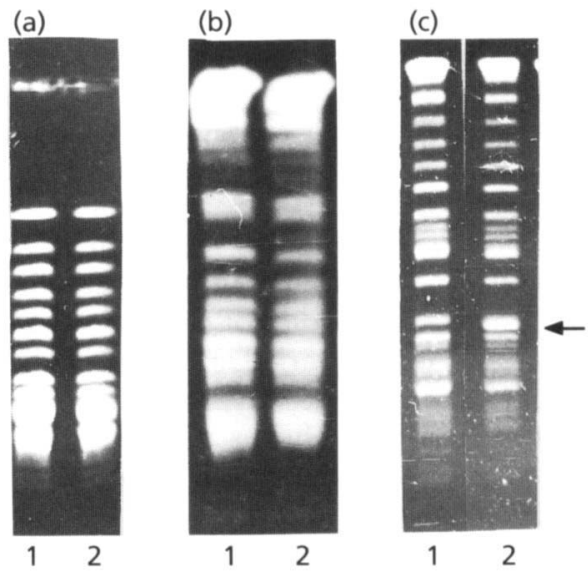

Fig. 4. PFGE separation of Xbal-generated genomic DNA fragments from $T$. ferrooxidans strains VKM-458 and VKM458As2. (a) $12 \mathrm{~V} \mathrm{~cm}^{-1}, 25 \mathrm{~s}$ pulse, $44 \mathrm{~h}$ run, $11^{\circ} \mathrm{C}$; (b) $10 \mathrm{~V} \mathrm{~cm}^{-1}$, $10 \mathrm{~s}$ pulse, $60 \mathrm{~h}$ run, $19^{\circ} \mathrm{C}$; (c) $12 \mathrm{~V} \mathrm{~cm}^{-1}, 5 \mathrm{~s}$ pulse, $68 \mathrm{~h}$ run, $20^{\circ} \mathrm{C}$. Lanes: 1, strain VKM-458; 2, strain VKM-458As2. The $28 \mathrm{~kb}$ fragment is indicated by an arrow.

gene(s) in the $28 \mathrm{~kb}$ fragment of T. ferrooxidans chromosomal DNA.

Expression of genes coding for resistance to toxic metals might be dependent on localization of mobile repeated DNA sequences. Such sequences have been found in both the chromosome and plasmids of several $T$. ferrooxidans strains (Yates \& Holmes, 1987; Yates et al., 1988). Holmes and coworkers (Holmes et al., 1988; Holmes \& Haq, 1989) proposed the hypothesis that mobile repeated DNA sequences are involved in the mechanism of $T$. ferrooxidans adaptation to variable environmental conditions, in evolution of gene structure and function, in regulation of expression of biochemical pathways, in the genetic information exchange between the strains, and in genomic translocations. Supporting evidence for these proposals came from experiments on adaptation of $T$. ferrooxidans to growth in the presence of $40 \mathrm{~g} \mathrm{Cu}^{2+} \mathrm{l}^{-1}$ (Holmes \& Haq, 1989). The authors analysed genomic locations of the family I repeats, prior to and after several months of subculturing of $T$. ferrooxidans under batch regime in the presence of high $\mathrm{Cu}^{2+}$ concentrations, and showed pronounced changes in the location of one of the repeats. These changes were suggested to be associated with the adaptation process. The following mechanism was proposed to explain the role of repeated DNA elements in the process of adaptation: the repeats could promote intrachromosomal recombination or plasmid-chromosomal recombination leading to new genomic combinations. Occurrence of repetitive sequences in both the chromosome and the plasmid provides the means of exchanging genetic information between these two parts of the genome and allows the plasmid to influence the expression of chromosomal genes. It is not inconceivable that translocation of such sequences within the genome can affect the location of restriction sites on chromosomal DNA thus leading to RFLP in T. ferrooxidans. Another 
reason for the occurrence of RFLP in T. ferrooxidans may reside in modification of restriction sites under the influence of environmental conditions: this can bring about inaccessibility of the sites to digestion by endonucleases and the resulting alteration of the fragment sizes. Monitoring of restriction patterns of chromosomal DNA in diverse $T$. ferrooxidans strains under standard conditions will give an insight into the stability of this character. Comparative studies of chromosomal DNA in one strain grown under varied growth conditions, i.e. with different electron donors, oxidation substrates, contents of nitrogen, phosphorus and toxic metals, and at varied $\mathrm{pH}$ values, will enable one to reveal the factors most essential for genetic stability of $T$. ferrooxidans. These studies can also indicate early changes in DNA structure which develop in response to environmental effects. PFGE proves to be an adequate method for the above studies of chromosomal DNA in different strains of T. ferrooxidans.

\section{REFERENCES}

Bender, L., Ott, M., Marre, R. \& Hacker, J. (1990). Genome analysis of Legionella ssp. by orthogonal field alternation gel electrophoresis (OFAGE). FEMS Microbiol Lett 72, 253-258.

Carle, G. F. \& Olson, M. V. (1985). An electrophoretic karyotype for yeast. Proc Natl Acad Sci US A 82, 3756-3760.

Giovannetti, L., Ventura, S., Bazzicalupo, M., Fani, R. \& Materassi, R. (1990). DNA restriction fingerprint analysis of the soil bacterium Azospirillum. J Gen Microbiol 136, 1161-1166.

Grothues, D. \& Tummler, B. (1987). Genome analysis of Pseudomonas aeruginosa by field inversion gel electrophoresis. FEMS Microbiol Lett 48, 419-422.

Holmes, D. S. \& Haq, R. U. (1989). Adaptation of Tbiobacillus ferrooxidans for industrial applications. In Biobydrometallurgy, pp. 116-127. Edited by J. Salley, R. G. L. McCready \& P. L. Wichlacz. Ottawa: Canadian Centre for Mineral and Energy Technology.

Holmes, D. S., Yates, J. R. \& Schrader, J. (1988). Mobile, repeated DNA sequences in Thiobacillus ferrooxidans and their significance for biomining. In Biobydrometallurgy, pp. 153-160. Edited by P. R. Norris \& D. P. Kelly. Chippenham: Research and Development Centre.

Karavaiko, G. I. (1989). Microorganisms and their role in biogeotechnology of metals. In Biogeotechnology of Metals. Practical Hand- book, p. 21. Edited by G. I. Karavaiko, G. Rossi, A. Agate, S. Grudev \& Z. Avakian. Moscow: Centre for International Projects, USSR State Committee for Environment Protection.

Leblond, P., Francou, F. X., Simonet, J.-M. \& Decaris, B. (1990). Pulsed-field gel electrophoresis analysis of the genome of Streptomyces ambofaciens strains. FEMS Microbiol Lett 72, 79-88.

Le Bourgeois, P., Mata, M. \& Ritzenthaler, P. (1989). Genome comparison of Lactococcus strains by pulsed-field gel electrophoresis. FEMS Microbiol Lett 59, 65-70.

Mathew, M. K., Smith, C. L. \& Cantor, C. R. (1988). Highresolution separation and accurate size determination in pulsedfield gel electrophoresis of DNA. 1. DNA size standards and the effect of agarose and temperature. Biochemistry 27, 9204-9210.

Okahashi, N., Sasakawa, C. \& Okada, N. (1990). Construction of a NotI restriction map of the Streptococcus mutans genome. $J$ Gen Microbiol 136, 2217-2223.

Peng, J.-B., Yan, W.-M. \& Bao, X.-Z. (1994). Plasmid and transposon transfer to Thiobacillus ferrooxidans. J Bacteriol 176, 2892-2897.

Rawlings, D. E. \& Kusano, T. (1994). Molecular genetics of Thiobacillus ferrooxidans. Microbiol Rev 58, 39-55.

Silverman, M. P. \& Lundgren, D. C. (1959). Studies on the chemoautotrophic iron bacterium Ferrobacillus ferrooxidans. I. An improved medium and harvesting procedure for securing high cell yields. $J$ Bacteriol 77, 642-647.

Tanskanen, E. L., Tulloch, D. L., Hillier, A. J. \& Davidson, B. E. (1990). Pulsed-field gel electrophoresis of SmaI digests of Lactococcal genomic DNA, a novel method of strain identification. Appl Environ Microbiol 56, 3105-3111.

Tudor, J. J., Marri, L., Piggot, P. J. \& Daneo-Moore, L. (1990). Size of the Streptococcus mutans GS-5 chromosome as determined by pulsed-field gel electrophoresis. Infect Immun 58, 838-840.

Yates, J. R. \& Holmes, D. S. (1987). Two families of repeated DNA sequences in Thiobacillus ferrooxidans. J Bacteriol 169, 1861-1870.

Yates, J. R., Cunningham, R. P. \& Holmes, D. S. (1988). IST2: an insertion sequence from Thiobacillus ferrooxidans. Proc Natl Acad Sci $U S A$ 85, 7284-7287.

Zakrzewska-Czerwinska, J., Kuczek, K., Gaszewska-Mastalarz, A. \& Mordarski, M. (1990). DNA restriction endonuclease analysis of some Streptomyces species. Actinomycetes 1, 79-82.

Received 15 July 1994; revised 4 November 1994; accepted 25 November 1994. 